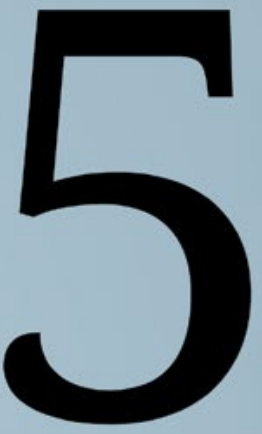


7月

8月

9月

11 月

10月

\section{URBAN, MOBILE AND GLOBAL}

Carolyn Cartier

3 月

4月

5月

7月

8月

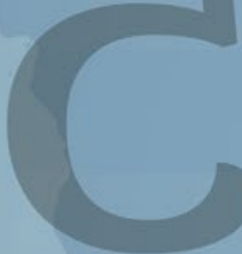


PEOPLE IN URBAN China travel, move house and commute longer distances than ever before. They also enjoy greater opportunities to change their lifestyles or move up the social ladder. The gradual removal of historical bans imposed by the Communist Party on unauthorised movement between cities (or from the countryside to the city) as well as owning property and travelling abroad make the ease of movement - mobility - novel and exciting.

Over the past year and a half, the anticorruption campaign has identified 'excessive mobility', as defined by all forms of 'extravagance' 铺张 or 奢靡 on the part of party and government officials, as being a danger to the wellbeing of the party-state. New prohibitions and regulations have put pressure on party and government officials to change their habits, alter their lifestyles and abandon any plans to establish a residential base overseas - in effect, to retreat from the Zeitgeist of mobility. This chapter considers the implications for the Shared Destiny of the Chinese in the context of movement between China and the world, particularly in relation to the Party's seemingly stringent anti-waste regulations. 


\section{A New Austerity}

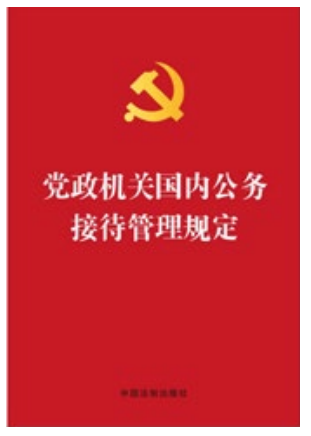

Rules on Party and Government Domestic Official Business Reception Management

Photo: xinxi1.yymcc.com
In November 2013, the Third Plenary Session of the Eighteenth Party Central Committee approved what are formally known as 'Party and Government Regulations for Strict Economic Practices to Combat Waste' 党政机关厉行节约反对浪费条例. The regulations, divided into twelve chapters and covering sixty-five items, outlined in great detail the management of government funds for everything from official travel, receptions and meetings to the use of vehicles and the renovation or construction of public buildings. This was the fourth tranche of bans and regulations issued since 2012 aimed at reforming and remoulding official conduct. They

complemented and extended the 'Twenty-six Item Directive' or 'Rules on Party and Government Domestic Official Business Reception Management' 党政机关国内公务接待管理规定 of December 2013; the January 2013 stipulations known as the 'Cage of Regulations'制度的笼子; and, the December 2012 'Eight Rules on Official Behaviour' 八项规定 that were a feature of China Story Yearbook 2013.

The new raft of regulations prescribed correct practices in mindnumbing detail and highlighted existing problems of official conduct. They targeted lavish dining out, banquets and receptions, gift-giving, publically funded travel and the perks that go with it. The prescriptions (and proscriptions) in each and every category will slow down growth in the urban economy, especially the service industries, such as restaurants and hotels, as well as the urban environment and the experience of living in Chinese cities more generally.

Among other things, the regulations specifically prohibited: bribery in all forms, including accepting expensive gifts; hiding illegally obtained income; misusing government funds; charging non-official fees and tourism in the guise of official travel. They ban local initiatives including celebra- 


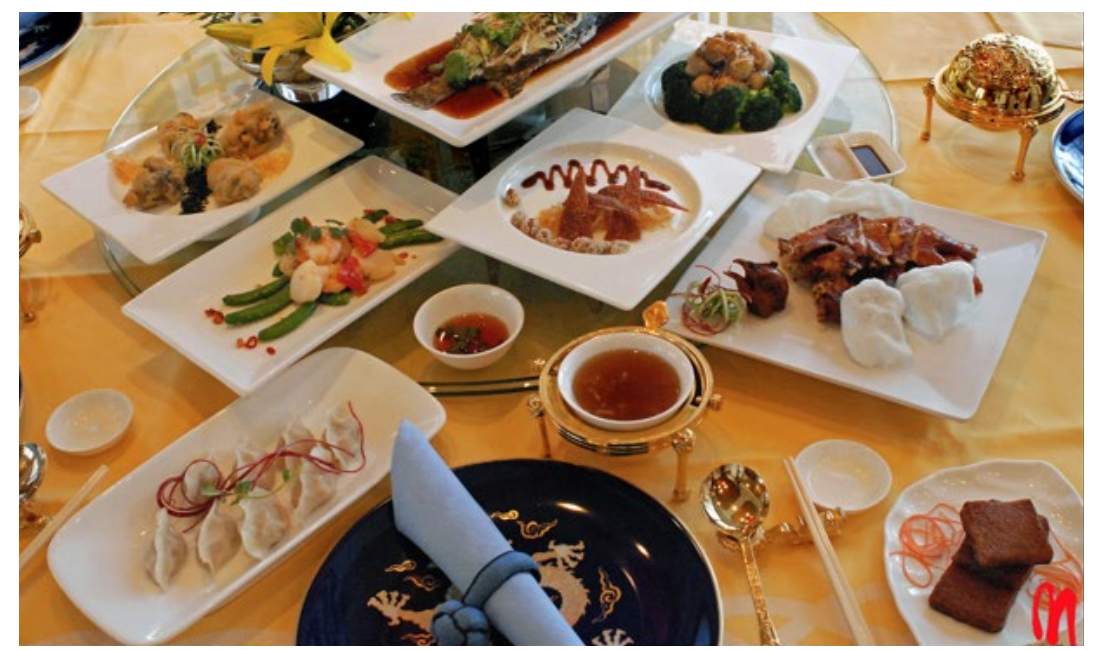

The newly approved 'Party and Government Regulations for Strict Economic Practices to Combat Waste' forbade lavish dining out, banquets and receptions, gift-giving, publically funded travel and the perks that go with it Photo: Frank Müller/Flickr

tions of local culture and the manufacture of products that have not been approved by higher authorities. They also proscribe non-approved changes to the administrative divisions, that is, the subnational boundaries, of governing districts. They demand that officials vacate non-standard office spaces, including long-term leases in hotels, and ban the construction of large and lavish new offices. Moreover, local governments must not, as they have taken to doing on a grand scale, build flash new urban landmarks 城市地标 or large-scale plazas.

The regulations promote budget restraint, rigorous audit practices, market price-based expenditure, the market reform of official vehicle procurement, and a two-tier, central and provincial-level approval process for related decisions that had previously only needed to be approved locally. They encourage the conservation of energy and resources, including of equipment and furnishings - no need to update computer laptops to the latest model or redecorate for no good reason. Government bureaus should adopt the 'paperless office' and co-ordinate to prevent duplication of functions. Propaganda or party PR departments must 'promote the con- 
in central Beijing. It ordered them to suspend business and 'adjust their way of thinking' 调整思路. The Hangzhou West Lake government also ordered luxury restaurants to close or develop new business models with moderately priced menus.

In December 2013, Xi Jinping took his austerity program into the streets, eating at the Qingfeng Steamed Bun Outlet 庆丰包子铺 in Beijing's Chaoyang district. He appeared to have arrived alone, ordered

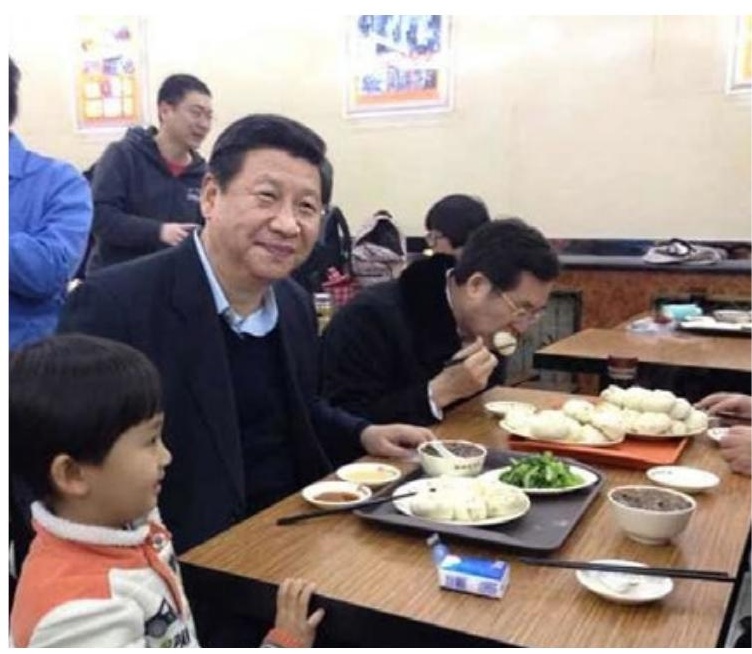

Xi Jinping eating a value meal subsequently dubbed the 'Chairman's Combo'

Photo: Weibo at the counter, paid twenty-one yuan (US\$3.50) for the meal and carried his tray to a table. Following his visit, to which the official media gave much publicity, customers flocked to the restaurant to order the 'Chairman's Combo' 主席套餐, a value meal of six steamed buns, a cold green vegetable and a soup of pig's liver and intestines. The owner, concerned with crushing competition for 'Xi's Seat', removed the table at which he sat as if it were an iconic object.

Yet if the image of Xi eating at the Qingfeng Steamed Bun Outlet seems to support small-scale entrepreneurs in the market economy, the reality is somewhat different. The Qingfeng chain is a subsidiary of the Huatian Group, a state-owned conglomerate that was co-founded by Beijing's Xicheng District Government and the State-owned Assets Supervision and Administration Commission of the State Council. The complex relationship between the state and the market results in many such examples in which private enterprise and state ownership coexist. For example, when corporations, not official bodies, sponsor banquets, the anti-waste 
regulations don't apply - yet the corporation itself may well be wholly or jointly state-owned.

\section{Curbing Excess at Home but Not Abroad?}

While aimed at bolstering the Party's legitimacy with the people and targeting official waste and corruption, the austerity campaign has also affected the relationships between political and economic elites, who together set trends in the urban consumer economy through their social relations and exchanges of favours.

Just two years ago many foreign luxury firms had planned to expand their businesses widely in China. But sales for international brands began

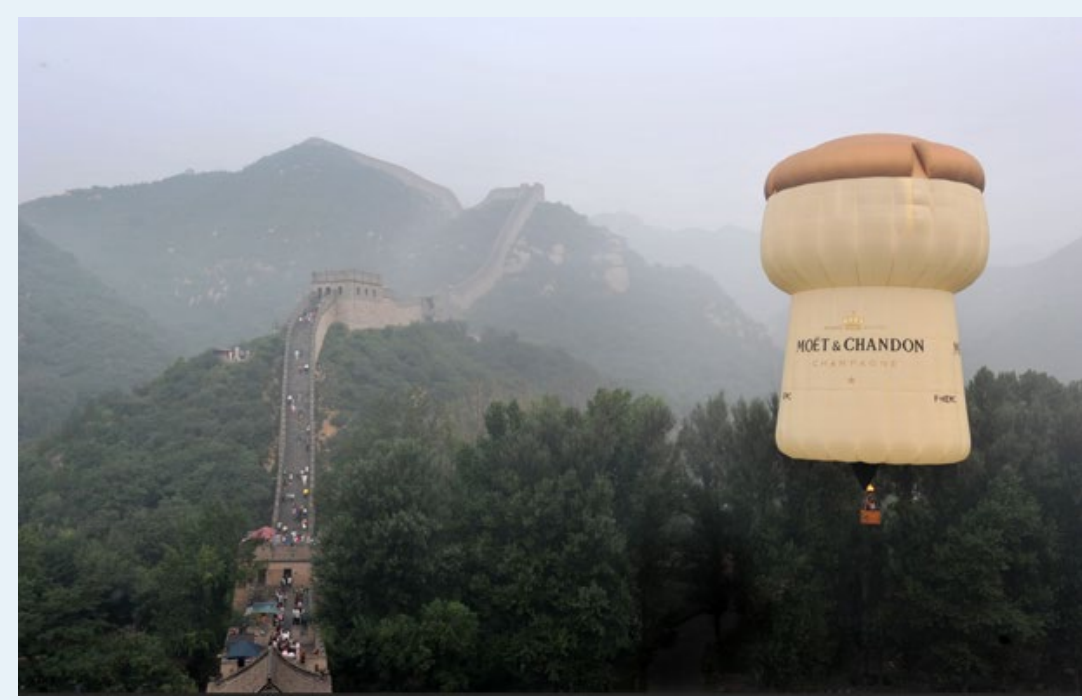

A French luxury goods conglomerate that owns Möet \& Chandon and Louis Vuitton reported that sales growth in China had dropped from ten to twenty percent to just five percent in 2013

Photo: us.moet.com 
to decrease in 2013 and by 2014 some luxury malls and international brand shops in Shanghai and Beijing had become consumer deserts. Although luxury brands continue to boost their profiles with bullish retail promotions and press releases, there is no doubt that conspicuous consumption has decreased as a result of the austerity campaign.

Yet by the first quarter of 2014, as global firms tracking luxury brands reported decreased sales in China, they noted that consumption of luxury goods by Chinese tourists overseas actually increased. In 2014, France, the home of many luxury brands, became the most favoured destination for middle-class Chinese tourists. It had already been high on the list of China's wealthy, measured as the top wealthiest twenty-five percent of the country's outbound tourists by income, who prefer it second only to

\section{Bling Loses its Sparkle, by Joanna (Yeejung) Yoon}

In 2012, China spent its way past the USA to become the biggest luxury goods market in the world, according to the Business of Fashion website. However, the same article notes that the growth of China's luxury market dropped to seven percent in 2012, down from more than thirty in previous years.

LVMH, a French luxury goods conglomerate that owns Möet \& Chandon and Louis Vuitton, reported that sales growth in China has dropped from ten to twenty percent to just five percent in 2013. In the same period, Salvatore Ferragamo's revenue growth in Asia halved to ten percent. When the price of shoemaker Tod's shares fell seven percent, the company blamed declining demand in Asia.

While industry says the anti-corruption campaign is responsible for declining sales, changing tastes are also partly responsible: the ostentatious embrace of luxury brands by déclassé nouveau riche has also taken some shine off the bling for the truly well-heeled.

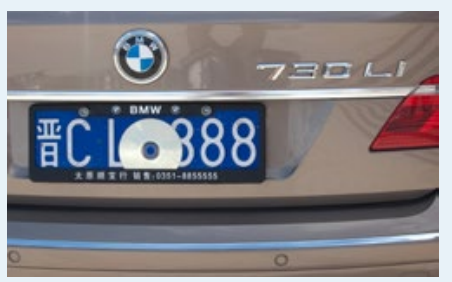

A lucky licence plate in China has become almost as much a status symbol as a car. Superstitious rich people spend a small fortune to purchase an auspicious plate. The luckiest number, and therefore most expensive, is eight, or ba, which rhymes with $f a$, the Chinese character for wealth Photo: Patrick Streule/Flickr 


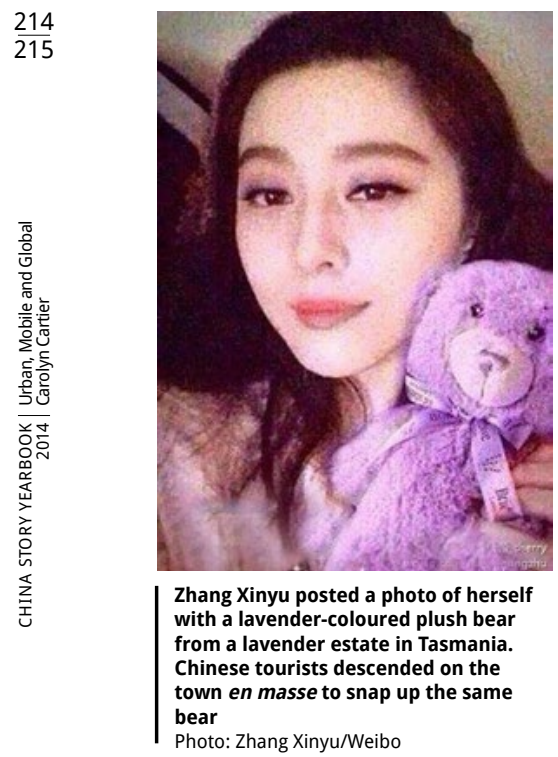

Australia, where the clean environment is the main draw.

Having seen Paris, some wealthy Chinese tourists took to pursuing the red wines of Bordeaux and Burgundy to the source, visiting the great chateaux and buying wine, or even whole cellars. Other travellers, led predominantly by women, would head south to seek out the fabled colours of Provence. These regional landscapes - from the Route des Grands Cru, Dijon to Santenay, to the lavender fields of Aix-en-Provence - have become widely known and even reproduced in China.

After the fashion model Zhang Xinyu 张馨予 posted a photo of herself with a lavender-stuffed, lavender-coloured plush bear from a lavender estate in Nabowla, Tasmania (the south-eastern island state of Australia), Chinese tourists descended on the town en masse to snap up the same bear - originally created as a way to deal with excess lavender. The demand grew so intense that the lavender estate limited sales to one per person. Even a Chinese quarantine services ban on the bear failed to have any immediate effect on sales.

Chinese citizens first gained the opportunity to travel outside the Mainland in the 1980s. In 1983, Hong Kong and Macao became the first places opened to Chinese tourists, but they could only travel as part of an organised tour. In 2003, in response to the SARS (Severe Acute Respiratory Syndrome, or 'avian flu') crisis, which caused a meltdown in Hong Kong's tourism industry and put many businesses in peril, Hong Kong implemented an 'individual visitor scheme' to boost mainland tourism. China's middle class shoppers, discouraged from buying quality goods and 


\section{WHERE THE ECONOMIC ELITE WENT IN 2013*}

1. Australia

2. France

3. Dubai

4. Switzerland

5. Maldives

6. United States

7. Japan

8. Germany

9. Singapore

10. New Zealand

*Defined as the top twentysix percent by income of 'outbound tourists'.

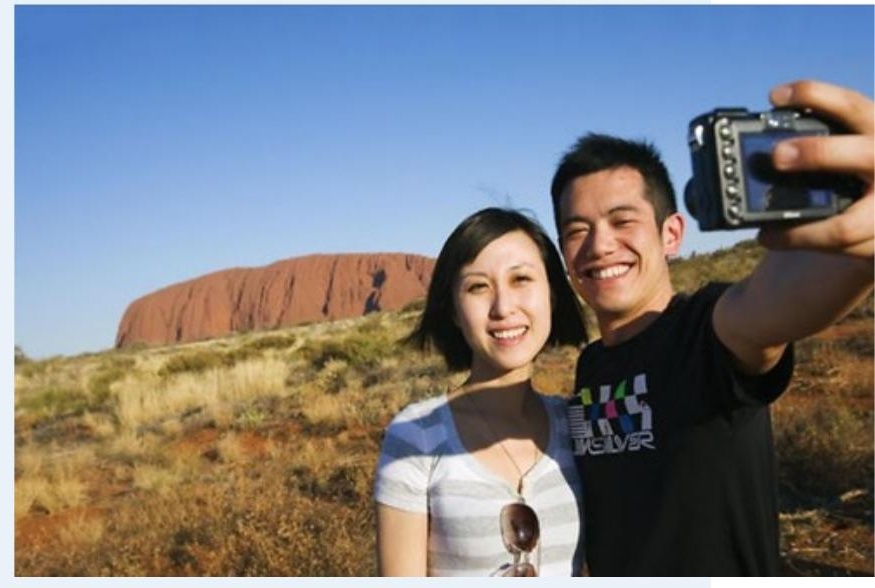

Australia was mainland China's most popular travel destination in 2013

Photo: Northern Territory Tourism

Data source: 2013 survey by FT (Financial Times) China Confidential survey of 1,227 middle income consumers in ten first-and second-tier cities.

http://www.ftchinaconfidential.com/outbound2013

luxury brand products in China because import duties and consumption taxes had made them far too expensive, found the same goods in Hong Kong's shopping malls - tax free. If the individual visitor scheme introduced new possibilities for travel and consumption, it was a privilege that was unevenly distributed. Just as the first economic experiments of Deng Xiaoping's program of Reform and Opening Up were first trialled in the Special Economic Zones of Shenzhen in the south before being extended to coastal cities and finally interior provinces, from south to north and east to west, the individual visitor scheme initially allowed independent travel only to residents of certain places in Guangdong. Later, this was extended to Beijing and Shanghai. Shenzhen, on the Hong Kong border, was able uniquely to offer multiple-entry visas for Hong Kong beginning in 2009 . 


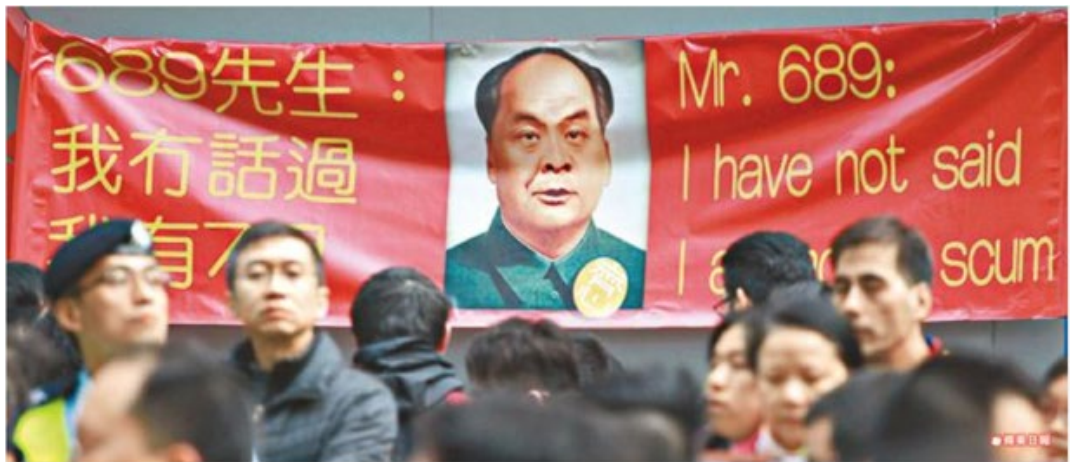

'Mr. 689' is the nickname Hong Kongers have given CY Leung, installed as Chief Executive of Hong Kong in 2012 with 689 votes by China's elite electoral committee. It became the unoffical symbol of the Hong Kong protests in 2014 Photo: hk.apple.nextmedia.com

During this time, the government gradually relaxed restrictions on travel by Chinese nationals to other countries. Through the 1990s, 'approved destinations' were confined to the Asia and Pacific region, with Australia and New Zealand being added to the list in 1999. Most European countries became approved destinations in 2004-2005, the United States in 2008 (by which time there were ninety-five countries on the list) and Canada in 2010. In 2013, Rwanda became the 116th country to make the list.

\section{Exceptional Zones: Hong Kong and Macao}

While mainland Chinese tourists boost the economies of their destinations, their arrival has not always been greeted with joy. In January 2014, the Hong Kong Secretary for Commerce and Development Gregory So Kam-leung 蘇錦樑 sparked public consternation when he claimed that Hong Kong, an urban area with a population of 7.2 million, could receive as many as seventy million tourists annually within three years, and up to one hundred million by 2023. In 2013, 40.8 million of the year's annual 54.3 million visitors arriving in Hong Kong came from mainland China. 


\section{WHERE MIDDLE-CLASS TOURISTS WANTED TO GO IN 2014}
1. France
6. Japan
2. United Kingdom
7. United States
3. Italy
8. Singapore
4. Germany
9. South Korea
5. Hong Kong
10. Switzerland

Data source: Hurun Report 2014, People's Daily Online, retrieved 26 January 2014

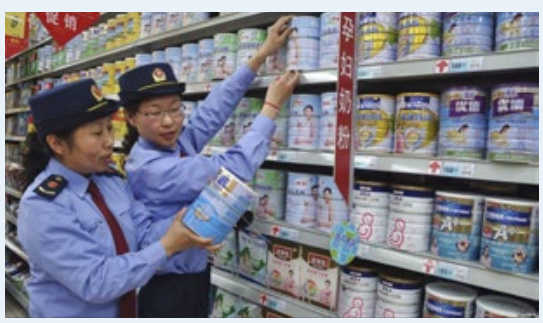

Chinese tourists are buying up infant milk powder everywhere they can get it. In Hong Kong the phenomenon has resulted in widespread shortages. Hong Kong authorities have imposed a two-tin export restriction on mainland Chinese tourists

Photo: voanews.com

There had already been both media criticism of and protests against Mainlanders ('locusts') for the bad manners that some displayed and the negative impact of mainland tourism in general (see the China Story Yearbook 2013: Civilising China, Forum 'Civilised Tourism', p.14). In March 2014, a particularly theatrical protest saw about one hundred people wearing Cultural Revolution-style costumes, waving red flags and holding posters with the Hong Kong Chief Executive CY Leung's 梁振英 face 'photoshopped' onto Mao Zedong's body as they shouted slogans like 'Love your country - buy Chinese products'愛國愛國貨. In response to this popular backlash, in May 2014, the New China News Agency published a list of 'do's and don'ts' for Mainlanders planning a visit to Hong Kong. The introduction to these guidelines reminded travellers that, 'when you go somewhere, follow local custom' 入乡随俗, elaborating on differences in daily life between the Mainland and Hong Kong.

Another concern is economic. In March 2014, The Economist named Hong Kong number one on its new 'crony-capitalism index', by a wide margin. The index tracks economic activity susceptible to 'rentseeking', which it defines as 'grabbing a bigger slice of the pie rather than 
WHAT'S IN AND WHAT'S OUT

IN

Eating in

Simple dishes

Spending time with family

Cars bought retail

Budget determines spending

Visits to the grassroots

Limited retinue

Short meetings

Plain wrapping

'Ordinary' facilities

Thrifty leadership

Recycle-reuse

OUT

Eating out

Exotic meats

Expending time in clubs

State-subsidised vehicles

Spending determines budget

Travel outside one's jurisdiction

Large entourages

Long conferences

Gaudy packaging

'Image' projects

Flashy conduct

Latest model making the pie bigger', and which often involves businesses gaining advantages over competitors as a result of political connections. It cites both Hong Kong and Singapore for their 'role as entrepôt for shiftier neighbours'.

Local authorities are also concerned about mainland visitors engaging in practices aimed at circumventing Chinese law, including the anti-waste regulations and the anti-corruption campaign. Some visitors make fraudulent use of UnionPay cards to circumvent Chinese laws restricting the amount of foreign currency a citizen can legally take out of the country. UnionPay is China's only domestic bankcard. It is used by all banks in China and operates with the approval of the People's Bank of China. It is widely accepted by ATMs in Hong Kong and Macao.

In 2006, Macao beat Las Vegas to take the title of biggest gambling centre in the world. By 2013, official figures for gaming revenue in Macao reached an unprecedented US $\$ 45$ billion. But an estimated further US $\$ 90$ billion in unreported income, twice the official total, came from the illegal use of UnionPay cards. The most common ruse is to pay for jewellery or other luxuries via UnionPay and then return the items for cash. The second type of fraud involves the use of handheld UnionPay terminals registered on the Mainland and smuggled into Macao in order to record transactions as domestic. 
In May 2014, the unprecedented growth of UnionPay card use in Macao raised concerns in Beijing that, as reported by the Macau Business Daily, 'tens of billions of yuan in illicit funds are being funnelled out of the Mainland and into casinos in direct contravention of national currency controls'. UnionPay quickly announced measures to 'combat overseas money laundering [and] capital flight'. The Macao Monetary Authority ordered casinos and shopping malls to search out and remove all unregistered UnionPay card machines. Subsequent media reports indicate that mainland visitors still commonly use UnionPay in Macao, but casinos and shops have not been able to add new payment terminals and there is ongoing official scrutiny.

\section{Globalisation of Capital and Residency Schemes}

Ever since the Global Financial Crisis of 2007-2008, well-heeled Chinese have invested in the housing market in many of the world's most desirable cities. Wealthy investors 'rationally overpay' to park capital in real estate that then routinely lies vacant. The decision to invest in property overseas is not surprising. In China, property reverts to the state after seventy years; there is no such thing as ownership in perpetuity. According to the global real estate services firm Jones Lang LaSalle, Chinese investment in real estate abroad increased by twenty-five percent in the first quarter of 2014 over the previous year to a total of US $\$ 2.1$ billion.

Among the most popular cities with cashed-up Chinese investors are those where housing is the least affordable: Hong Kong, Vancouver, Sydney, San Francisco, San Jose (Silicon Valley), Melbourne, New York, London,

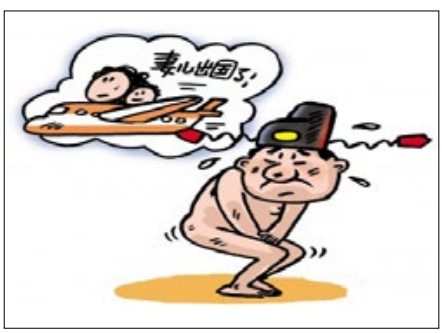

'Naked officials': Party and government officials who send their families and suspicious fortunes to Hong Kong or Western countries, including tax havens with no extradition treaty with China, without a legitimate work-related reason Photo: Weibo 
Los Angeles and Auckland. As a result, in many of these cities there is concern that Chinese investment is pushing housing prices out of the reach of local residents. In February 2014, Canada cancelled its Immigrant Investment Program, which had some 65,000 pending applications, seventy percent of which were from China, claiming that the scheme had undervalued Canadian permanent residency.

In Australia, there have been conflicting reports on the impact of foreign investment, of which Chinese investment is a significant part, on the real estate market. The law holds that non-residents are allowed to purchase only new-build housing (thus stimulating construction), while some figures suggest that non-resident purchases also factors in the 15.4 percent rise in housing prices in Sydney and 9.2 percent rise in Melbourne over the twelve months to June 2014. A parliamentary inquiry into the effect of foreign buyers on Australian real estate prices has suggested new rules and stricter enforcement of existing rules, while reported reactions among 'cashed-up foreign real estate investors view the existing $\$ 85,000$ fine for buying existing dwellings just a cost of doing business'.

A financial industry survey found that forty-seven percent of 'high net worth' individuals planned to move overseas. From the standpoint of those running the anti-corruption campaign, the problem is that Chinese investing overseas includes government officials whose incomes should not allow it. A survey by the Chinese Academy of Social Sciences revealed that half of the party and government officials at provincial and county levels were considering how to acquire foreign nationality or residency for their children. Bureaucrats whose spouses, children - and assets have been moved abroad are called 'naked officials' 裸体官员, known colloquially as luoguan 裸官 (see Forum 'Chinese Families Going Global?', p.230). According to the Global Financial Integrity Group, which monitors illegal money flows, no less than US $\$ 3$ trillion had been illicitly spirited out of China in the six years to 2011.

In a 2013 speech on the drive for clean government ('honest and clean party and government rule’ 党风廉政), Wang Qishan, head of the Cen- 


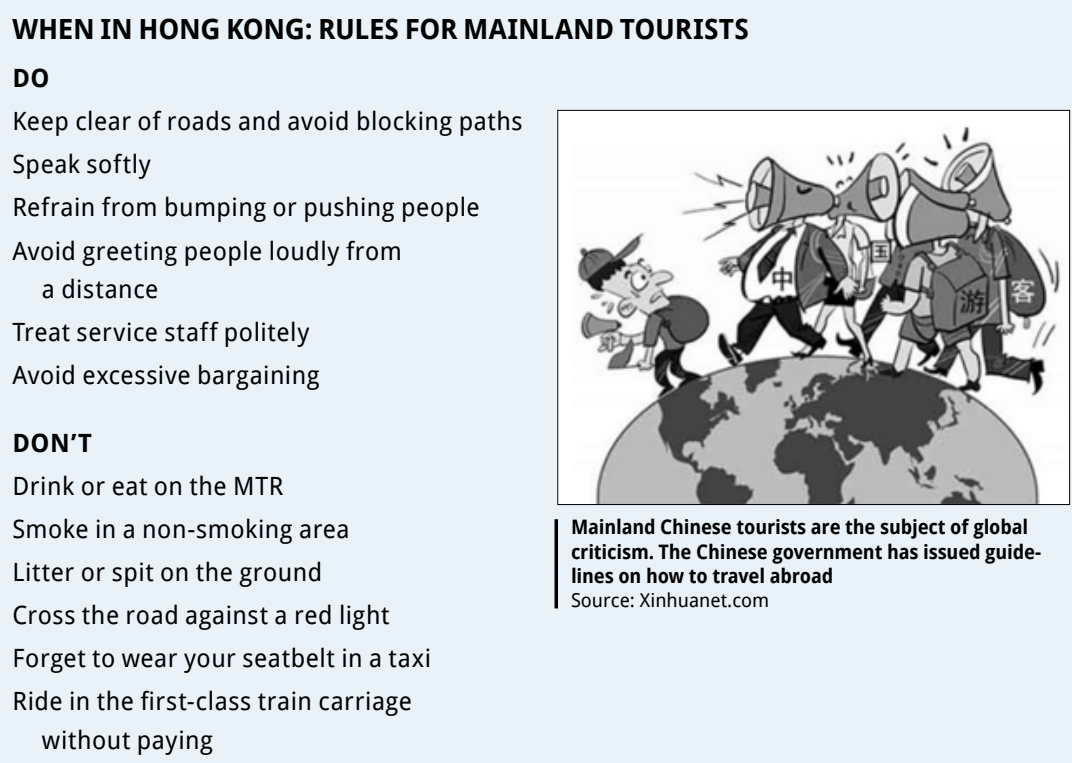

Source: Xinhua News Agency, 9 May 2014

tral Commission for Discipline Inspection, previewed measures to bring China's 1.18 million 'naked officials' into line. Wang identified how the problem of nepotism, like all forms of corruption, interferes with the development and operation of the market. But his observation exposes the contradiction between party-state expectations for political elites and the rational choices individuals make in the global market.

The Hong Kong Capital Investment Entrance Scheme bars applicants from China but makes an exception for Chinese nationals who have permanent residence in another country. For a fee of HK\$200,000 (US\$25,800) Hong Kong immigration agents help mainland citizens obtain residency permits in other countries with lax requirements for residency so that they can take advantage of this loophole. Of more than 17,000 mainland 


\section{WHERE CHINESE TRAVELLERS GO}

Approved Destination Status agreements with China, by year.

\section{Year Destination}

1983 Hong Kong, Macao

1988 Thailand

1990 Malaysia, Singapore

1992 Philippines

1998 South Korea

1999 Australia, New Zealand

2000 Brunei, Cambodia, Japan, Myanmar, Vietnam

2002 Egypt, Indonesia, Malta, Nepal, Turkey

2003 Croatia, Cuba, Germany, Hungary, India, Maldives, Pakistan, South Africa, Sri Lanka

2004 Austria, Belgium, Cyprus, Czech Republic, Denmark, Estonia, Ethiopia, Finland, France, Greece, Iceland, Ireland, Italy, Jordan, Kenya, Latvia, Liechtenstein, Lithuania, Luxembourg, Mauritius, Netherlands, Norway, Poland, Portugal, Romania, Seychelles, Slovenia, Slovakia, Spain, Sweden, Switzerland, Tanzania, Tunisia, Zambia, Zimbabwe

2005 Antigua and Barbuda, Barbados, Brazil, Chile, Fiji, Jamaica, Lao PDR, Mexico, Northern Mariana Islands, Peru, Russia, United Kingdom, Vanuatu

2006 Bahamas, Grenada, Mongolia, Tonga

2007 Andorra, Argentina, Bangladesh, Bulgaria, Uganda, Morocco, Monaco, Namibia, Venezuela, Oman, Syria

2008 French Polynesia, Israel, Taiwan, United States

2009 Cape Verde, Dominican Republic, Ecuador, Ghana, Guyana, Mali, Montenegro, Papua New Guinea, United Arab Emirates

2010 Canada, Lebanon, Federated States of Micronesia, North Korea, Uzbekistan, Serbia

2011 Iran

2012 Madagascar, Cameroon, Colombia, Samoa

2013 Rwanda

Source: Chinese National Tourism Association (www.cnta.gov.cn) 
Chinese investors in the Hong Kong scheme, a group that constitutes eighty-seven percent of the total, 13,300 have residency papers from Gambia and Guinea-Bissau. In the third quarter of 2013, applicants for Hong Kong's program more than doubled from the previous year to 3,380, a record high. Officials from the People's Republic may apply with civilian mainland identity cards while maintaining household registration status and businesses in China.

Applications from mainland students to Hong Kong universities have also increased significantly, including applications from mature-age students. In the 2010s, the proportion of postgraduate students from mainland China studying at Hong Kong universities increased to more than half. In the academic year 2011-2012, out of fewer than 7,000 postgraduate students at Hong Kong universities, 4,298 were from China. By 2012-2013, the number increased to 4,586 . Most pursue master's programs in business, finance, accountancy and other professional degrees. The postgraduate visa is a more economical way to obtain Hong Kong residency than the capital investment scheme. It allows graduates one year to find a job and, after another six years, the opportunity to apply for permanent residency.

After Canada cancelled its popular (and relatively low-cost) Immigrant Investment Program, similar schemes in Australia, Europe and the US became even more popular. In November 2012, Australia introduced the Significant Investor Visa, which mandated an investment of AU\$5 million in a local business or approved managed funds for those who would want to obtain permanent residency. Within a year, eighty-five percent of the applications came from mainland Chinese. In October 2014, the Australian government went even further, announcing a new 'premium' investor visa for applicants investing AU\$15 million or more in the country, who can then get permanent residence in one year.

In Europe, the direct purchase of real estate entitles the buyer to resident status in Portugal, Spain, Greece and Cyprus. In 2012, Portugal introduced a '318 Golden Visa'; this allows the granting of permanent residency after five years and EU residency after an additional one year for buyers of 
real estate with a value greater than $€ 500,000$. In the first year, 248 of 400 successful applicants came from China.

In August 2014, the US State Department announced that the annual quota of investment visas for permanent residency in the United States had filled early, with Chinese investors making up eighty percent of the year's allocation. Demand from China for the US scheme exceeds that from any other county, and it increased after Canada shut down its program.

\section{Conclusion}

When the Party launches a political campaign, superficial or at least statistically evident results can be quick. But such campaigns have historically played out only in China itself. The current austerity campaign has implications for the behaviour of Chinese elites and officials in a global context. In October 2014, the Australian Federal Police revealed they were working with their Chinese counterparts to seize the assets of corrupt officials who had brought hundreds of millions of dollars of illicit earnings into Australia.

How will political and economic elites react to the new pressures for clean government in relation to the way they take up global opportunities? How will regulations set by the Party work in an era of international capital mobility? What are their implications for national loyalties, food security and environmental quality at home and abroad?

As noted elsewhere in this volume, the anti-corruption campaign ostensibly sought to clear the way for the implementation of a new wave of economic reforms. Its anti-waste directives expose and address popular outrage at official corruption and excess consumption. But it also reveals fundamental contradictions in a political-economic system in which the state embraces market discourses and desires rather than focusing on the establishment and long-term maintenance of viable market institutions. 
The political campaign is unlikely to be able to rein in the new urban mobility.

Domestic and international mobility in China has increased dramatically over the past thirty years. The impending loosening and reform of the once-strict household registration system will grant legal residency status to millions of urban migrants; it will address the problems of the urban underclass and increase their potential for social mobility in China's burgeoning cities. At the same time, urban professionals are growing anxious about the future in which they share social welfare with millions of new urban citizens. New constellations of mobility make the cities of the outside world, by comparison, desirable and realistic destinations and sites of comparative possibility. The Shared Destiny of groups and classes in China extends their desire to embrace a global destiny - the ramifications of which are hard to predict. 
This text is taken from Shared Destiny, edited by Geremie R Barmé, Linda Jaivin and Jeremy Goldkorn, published 2015 by ANU Press, The Australian National University, Canberra, Australia. 